\title{
Hydrogen production by conversion of ethanol injected into a microwave plasma*
}

\author{
Dariusz Czylkowski ${ }^{1, a}$, Bartosz Hrycak $^{1}$, Mariusz Jasiński ${ }^{1}$, Mirosław Dors ${ }^{1}$, and Jerzy Mizeraczyk ${ }^{2}$ \\ ${ }^{1}$ Institute of Fluid Flow Machinery, Polish Academy of Sciences, Fiszera 14, 80-231 Gdańsk, Poland \\ ${ }^{2}$ Department of Marine Electronics, Gdynia Maritime University, Morska 81-87, 81-225 Gdynia, Poland
}

Received 31 August 2017 / Received in final form 17 October 2017

Published online 12 December 2017

(C) The Author(s) 2017. This article is published with open access at Springerlink.com

\begin{abstract}
Reforming of gaseous and liquid hydrocarbon compounds into hydrogen is of high interest. In this paper we present a microwave $(2.45 \mathrm{GHz})$ plasma-based method for hydrogen production by conversion of ethanol $\left(\mathrm{C}_{2} \mathrm{H}_{5} \mathrm{OH}\right)$ in the thermal reforming process in nitrogen plasma. In contrast to our earlier investigations, in which $\mathrm{C}_{2} \mathrm{H}_{5} \mathrm{OH}$ vapour was supplied into the microwave plasma region either in the form of a swirl or axial flow, in this experiment we injected $\mathrm{C}_{2} \mathrm{H}_{5} \mathrm{OH}$ vapour directly into the nitrogen microwave plasma flame, behind the microwave plasma generation region. The experimental results were as follows. At an absorbed microwave power of $5 \mathrm{~kW}, \mathrm{~N}_{2}$ (plasma-generating gas) swirl flow rate of $2700 \mathrm{NL}\left(\mathrm{N}_{2}\right) / \mathrm{h}$ and $\mathrm{C}_{2} \mathrm{H}_{5} \mathrm{OH}$ mass flow rate of $2.7 \mathrm{~kg}\left(\mathrm{C}_{2} \mathrm{H}_{5} \mathrm{OH}\right) / \mathrm{h}$ the hydrogen production rate was $1016 \mathrm{NL}\left(\mathrm{H}_{2}\right) / \mathrm{h}$, which corresponds to the energy yield of hydrogen production $203 \mathrm{NL}\left(\mathrm{H}_{2}\right) / \mathrm{kWh}$. After the $\mathrm{C}_{2} \mathrm{H}_{5} \mathrm{OH}$ conversion the outlet gas contained $27.6 \%$ (vol.) $\mathrm{H}_{2}, 10.2 \% \mathrm{CO}, 0.2 \% \mathrm{CO}_{2}, 4.8 \% \mathrm{CH}_{4}, 4.3 \% \mathrm{C}_{2} \mathrm{H}_{2}, 3.7 \% \mathrm{C}_{2} \mathrm{H}_{4}$ and $3.7 \% \mathrm{C}_{2} \mathrm{H}_{6}$. These results are comparable to those obtained in our earlier investigations, in which different methods of $\mathrm{C}_{2} \mathrm{H}_{5} \mathrm{OH}$ vapour supply to the microwave plasma generation region were employed.
\end{abstract}

\section{Introduction}

It is a common opinion that hydrogen has a great role to play as an energy carrier in the future energy sector. Production of hydrogen from non-renewable (fossil fuels) and renewable sources (biomass, water) are of high interest [1-4]. Considerable efforts have been and are still being made in improving existing and developing new advanced hydrogen production techniques $[5,6]$. Reforming of gaseous and liquid hydrocarbon compounds seems to be an attractive method for hydrogen production $[7,8]$. For that purpose such processes as thermal reforming, dry reforming, steam reforming (mainly of natural gas), partial oxidation and auto-thermal reforming have been tested. Ethanol, nowadays most available bio-fuel is considered to be a promising candidate for renewable hydrogen production using the reforming processes referred to above $[7,9-13]$.

Recently another technology has been proposed for the so-called distributed hydrogen production [8]. This technology uses microwave-excited plasmas, which are suitable for reforming gaseous and vapourized liquid compounds containing hydrogen. The attractiveness of microwave plasma for hydrogen production was proved

\footnotetext{
* Contribution to the Topical Issue "Advances in Plasma Chemistry", edited by Slobodan Milošević, Nikša Krstulović, and Holger Kersten.

a e-mail: dczylkowski@imp.gda.pl
}

when methane (in mixture with $\mathrm{CO}_{2}$ and $\mathrm{H}_{2} \mathrm{O}$ ) was reformed into hydrogen in the so-called waveguidesupplied metal-cylinder-based microwave plasma source (MPS) [14]. This resulted in a hydrogen production rate of $2150 \mathrm{NL}\left(\mathrm{H}_{2}\right) / \mathrm{h}$ and in a hydrogen production energy yield of $480 \mathrm{NL}\left(\mathrm{H}_{2}\right) / \mathrm{kWh}$ [15]. It is worth noting that the hydrogen production energy yield of $480 \mathrm{NL}\left(\mathrm{H}_{2}\right) / \mathrm{kWh}$ is close to meet the U.S. Department of Energy (DOE) requirement of producing $\mathrm{H}_{2}$ at a production yield of $672 \mathrm{NL}\left(\mathrm{H}_{2}\right) / \mathrm{kWh}$ by 2020 to be capable of competing with the well-established processes for hydrogen production [8]. Analyses show (e.g. [8]) that alcohol vapours seem to be promising feedstock for hydrogen production using the microwave plasma, and the alcohol-based plasma-chemical systems may reach DOE's target 2020 of hydrogen energy yield. It seems that the relatively high values of the hydrogen production rate and energy yield demonstrated by the microwave methods used for hydrogen production from methane $[14,15]$ make these methods attractive for further development towards approaching the DOE 2020 target.

The waveguide-supplied metal-cylinder-based MPS is a reliable microwave plasma generator when nitrogen is used as a plasma-generating gas. Mixing the nitrogen with other compounds which disintegrate in the plasma in the plasma generation region may cause malfunctioning of the MPS. This may be the case when reforming of alcohols in the nitrogen-based microwave plasma is to be performed. Very often one of the alcohol reforming products is solid carbon, called by us soot. The presence of soot in the 


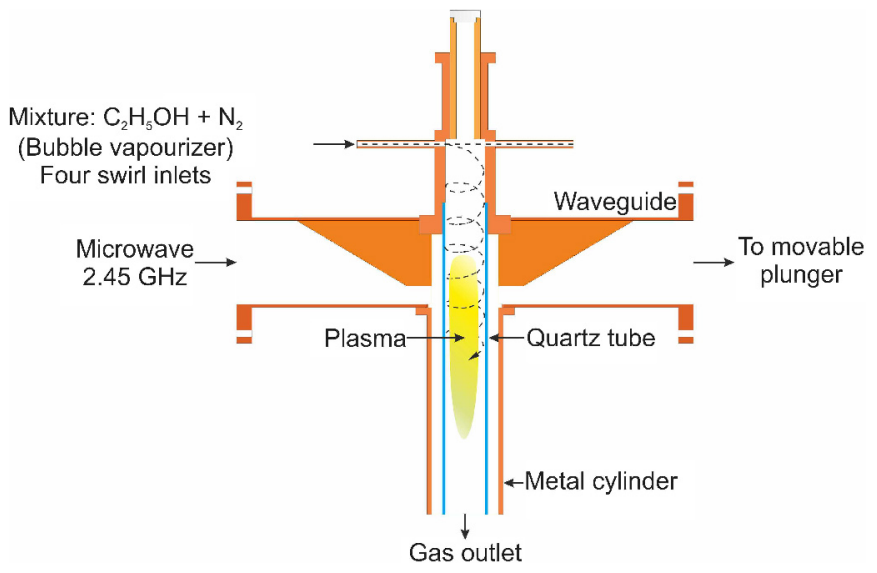

Fig. 1. Schematic drawing of the MPS with $\mathrm{C}_{2} \mathrm{H}_{5} \mathrm{OH}$ vapour swirl supply system (bubble vapourizer for forming the mixture of $\mathrm{C}_{2} \mathrm{H}_{5} \mathrm{OH}$ vapour and $\mathrm{N}_{2}$ ) [18].

nitrogen plasma-generating gas and the soot deposits on the MPS walls around the plasma generation region was found by us a serious reason for an unreliable operation of the MPS.

Four reactions may be involved in soot formation in the plasma region $[16,17]$

$$
\begin{gathered}
2 \mathrm{CO} \leftrightarrow \mathrm{C}+\mathrm{CO}_{2} \\
\mathrm{CH}_{4} \leftrightarrow \mathrm{C}+2 \mathrm{H}_{2} \\
\mathrm{CO}+\mathrm{H}_{2} \leftrightarrow \mathrm{C}+\mathrm{H}_{2} \mathrm{O} \\
\mathrm{C}_{n} \mathrm{H}_{2 n}+\mathrm{H}_{2} \leftrightarrow n \mathrm{C}+(n+1) \mathrm{H}_{2}
\end{gathered}
$$

Soot formation via reactions (1) and (4) becomes increasingly important at higher temperature, which usually occurs in the plasma generation region. Favoured soot production in this sensitive region may rapidly result in severe microwave plasma fluctuations or even in the plasma extinguishing.

The waveguide-supplied metal cylinder based nozzleless MPS offers several ways of supplying the working gas (nitrogen in our case) and the hydrogen precursor (alcohol vapour). The reason of applying nitrogen as a working gas for plasma generation was its low price (e.g. in comparison to argon), relatively neutral impact on the environment and high gas temperature stipulating efficient production of hydrogen from ethanol.

In our earlier investigations of ethanol reforming, ethanol vapour was introduced into the microwave plasma region either as a swirl flow - Figures 1 and $2[18,19]$ or an axial flow - Figure 3 [20]. In both cases nitrogen was supplied in the form of a swirl flow. We found that all the ethanol supply systems operated unreliable if the ethanol mass flow rate was high. We will return to this matter later, when discussing results of the experiment presented in this paper.

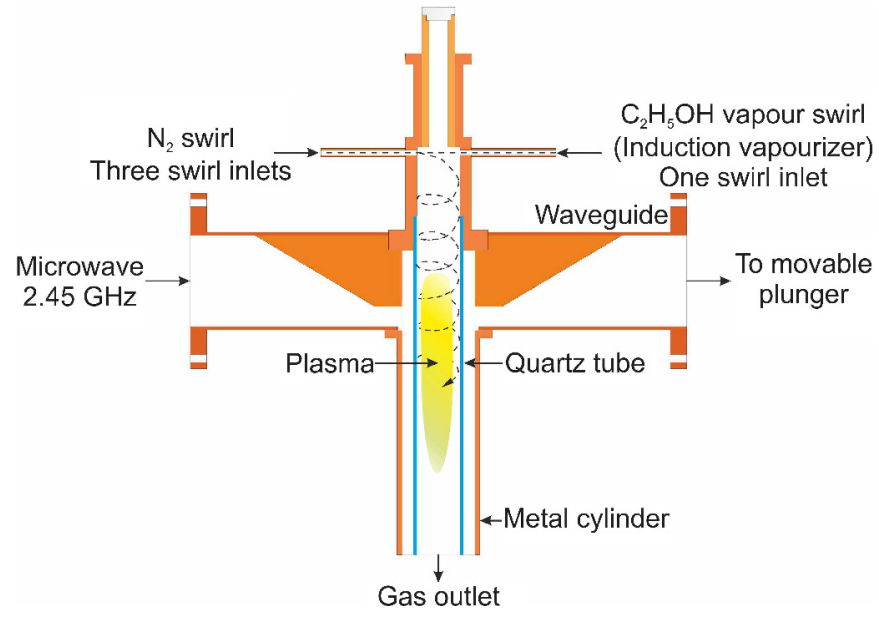

Fig. 2. Schematic drawing of the MPS with $\mathrm{C}_{2} \mathrm{H}_{5} \mathrm{OH}$ vapour swirl supply system (induction vapourizer for forming $\mathrm{C}_{2} \mathrm{H}_{5} \mathrm{OH}$ vapour) [19].

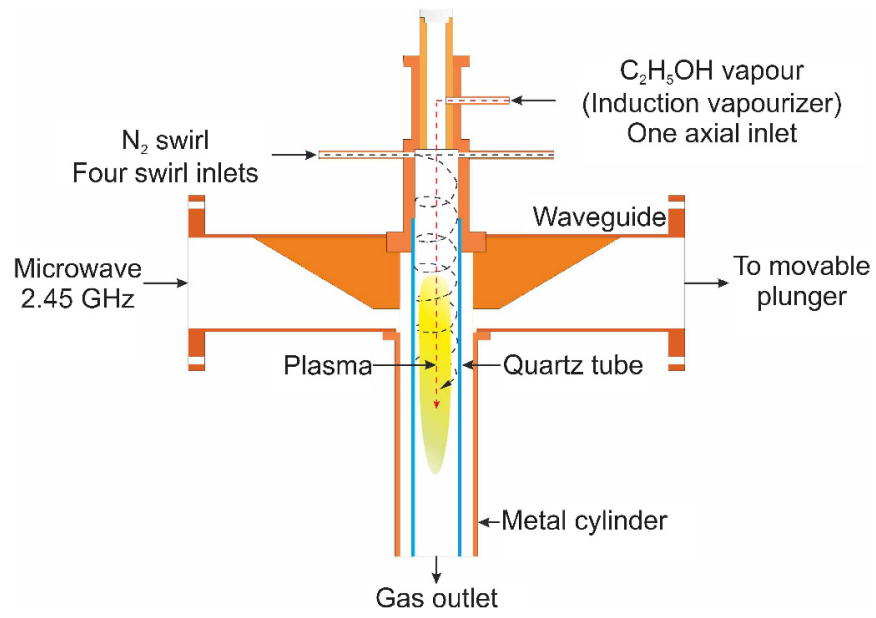

Fig. 3. Schematic drawing of the MPS with $\mathrm{C}_{2} \mathrm{H}_{5} \mathrm{OH}$ vapour axial supply system (induction vapourizer for forming $\mathrm{C}_{2} \mathrm{H}_{5} \mathrm{OH}$ vapour) [20].

In these investigations we injected ethanol vapour directly into the nitrogen microwave plasma flame, behind the plasma generation region. Such an ethanol vapour injection method was supposed to prevent a generation of soot in the plasma generation region. Using nitrogen as the gas-generating plasma in these investigations means that ethanol conversion occurs in the plasma thermal reforming process. The other reforming processes, such as the dry reforming with $\mathrm{CO}_{2}$, steam reforming with $\mathrm{H}_{2} \mathrm{O}$, partial-oxidation reforming with $\mathrm{O}_{2}$, or auto-thermal reforming (the combination of steam- and partial-oxidation reforming) are not the subject of these investigations.

\section{Experimental procedure and setup}

A block diagram of the experimental setup is shown in Figure 4. It consists of a microwave generator system, a microwave power measuring system, an impedance 


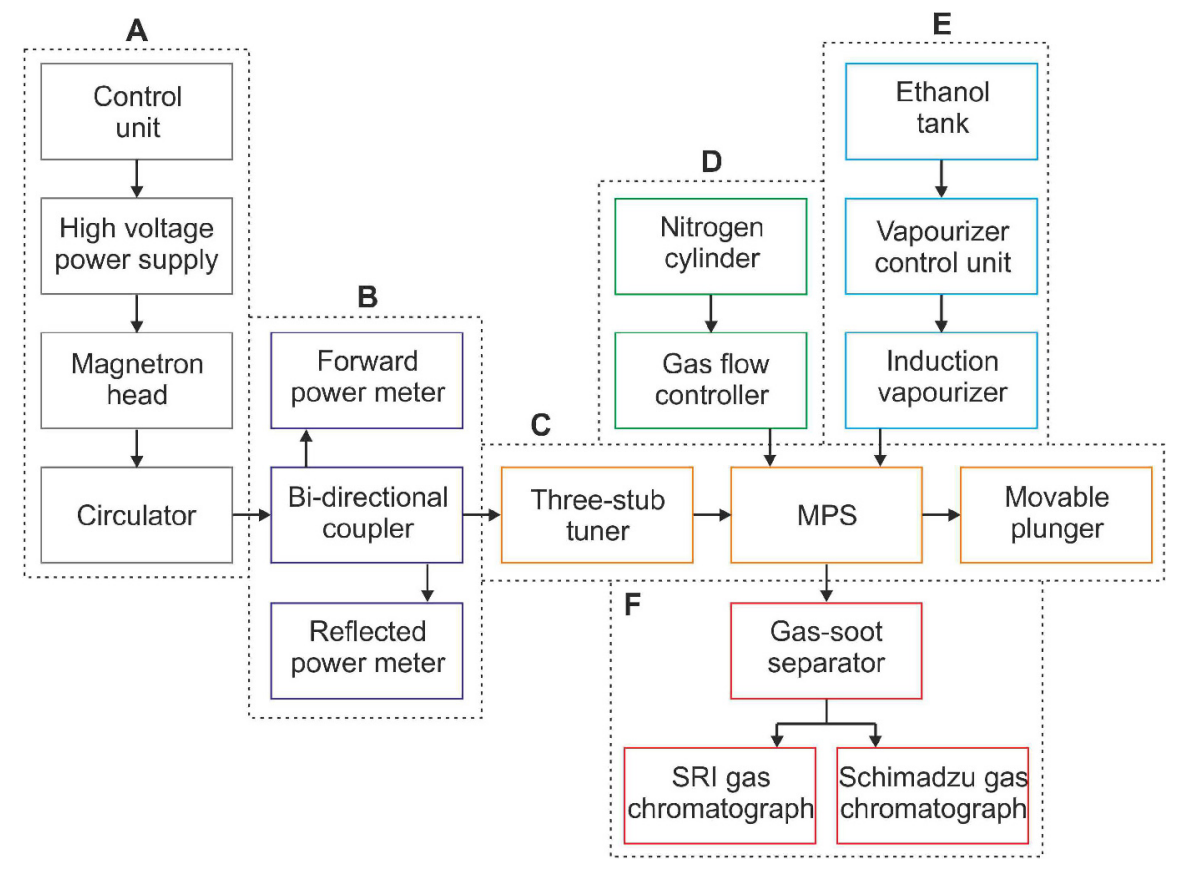

Fig. 4. Block diagram of the experimental setup: A - microwave generator system, B - microwave power measuring system, C - microwave plasma source (MPS) with impedance matching system, D - nitrogen supply system, E - ethanol supply system, $\mathrm{F}$ - outlet gas handling and analysis system.

matching system, a MPS, a nitrogen supply system, an ethanol supply system, and outlet gas handling and analysis system. The microwave generator system comprises a magnetron head, a high voltage power supply with a control unit, and a circulator. The system generates the electromagnetic $\mathrm{CW}$ wave of a frequency of $2.45 \mathrm{GHz}$ with an output power controlled in the range of $0.6-6 \mathrm{~kW}$. The circulator protects the magnetron head against the damage danger which could arise from the microwave energy reflected by a microwave receiver to which the microwave energy is supplied. The microwave energy from microwave generator system is supplied via a standard rectangular waveguide to the MPS (a receiver). On its way to the MPS the microwave energy is analysed by the microwave power measuring system composed of calibrated directional couplers (marked as a bi-directional coupler in Fig. 4) and forward and reflected power meters. The calibrated directional couplers sample the forward and reflected microwave power at the MPS input. This enables measuring the microwave power absorbed by the MPS. The microwave duct is equipped with the impedance matching system. Its parts: a three stub tuner and a movable plunger are preceding and following the MPS, respectively. Matching the impedance in the microwave waveguide duct improves efficiency of the microwave energy transfer from the microwave generator system to the MPS. Nitrogen, which plays a role of the working gas in this experiment is delivered to the MPS by the nitrogen supply system with a mass flow controller. Ethanol in the form of vapour is delivered to the MPS by the ethanol supply system, equipped with an induction heating vapourizer having a control unit. At the MPS outlet the outlet gas handling and analysis system is placed. It includes a gas-soot separator for cleaning the outlet gas from the soot produced during the ethanol reforming and SRI and Shimadzu gas chromatographs for the inlet and outlet gas composition analysis. Both chromatographs are controlled by a software installed in a PC.

The MPS used in this experiment was a waveguidesupplied metal cylinder based nozzleless microwave $(2.45 \mathrm{GHz})$ plasma source [14] - Figure 5. A similar MPS was used in our earlier investigations of ethanol reforming by microwave plasma [18-20]. However, in contrast to our earlier investigations, in which ethanol vapour was introduced into the microwave plasma region either as a swirl flow $[18,19]$ or an axial flow [20], in this experiment we injected ethanol vapour directly into the plasma flame, behind the plasma generation region (inside the waveguide).

In this experiment nitrogen was the working gas (serving mainly as the plasma-generating gas). Nitrogen flow was supplied via four swirl-forming ducts into the plasma region as a swirl flow. Ethanol vapour at a temperature of $250^{\circ} \mathrm{C}$ was produced in the induction heating vapourizer and supplied radially via three ducts into the plasma flame, behind the plasma generation region. Such a way of the introduction of $\mathrm{C}_{2} \mathrm{H}_{5} \mathrm{OH}$ vapour into the microwave plasma was aimed at avoiding the soot production in the plasma generation region. The presence of soot in the plasma generation region in our earlier investigations caused a serious malfunction of the MPSs. The experimental investigations were performed for the nitrogen flow rate of $2700 \mathrm{NL} / \mathrm{h}, \mathrm{C}_{2} \mathrm{H}_{5} \mathrm{OH}$ mass flow rate ranged from $0.14 \mathrm{~kg} / \mathrm{h}$ to $2.7 \mathrm{~kg} / \mathrm{h}$ and absorbed microwave power between $2 \mathrm{~kW}$ and $5 \mathrm{~kW}$.

The investigations concerned determination of the following MPS performance parameters: the hydrogen production rate in $\mathrm{NL}\left(\mathrm{H}_{2}\right) / \mathrm{h}$, the energy yield of hydrogen 


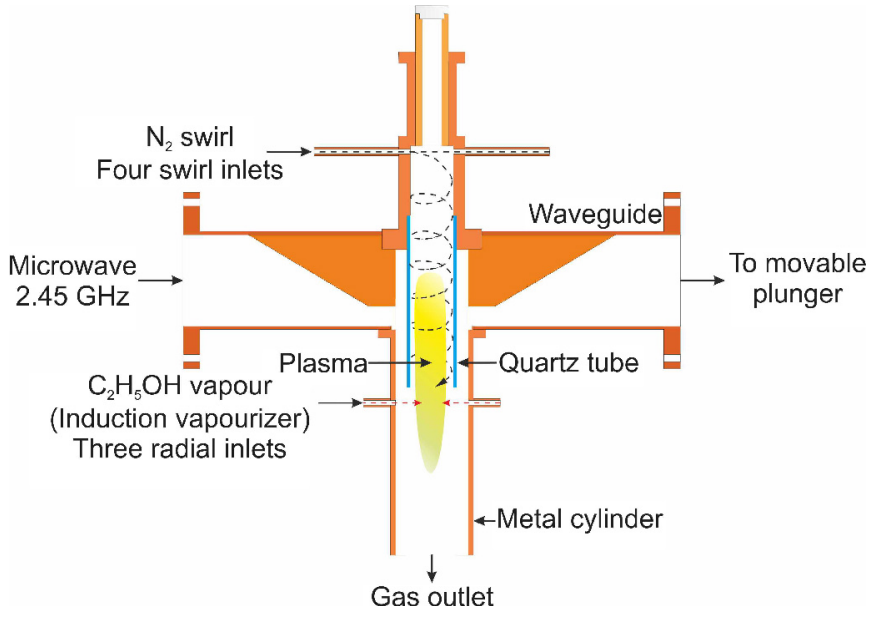

Fig. 5. Schematic drawing of the MPS with $\mathrm{C}_{2} \mathrm{H}_{5} \mathrm{OH}$ vapour supplied from the induction vapourizer directly into the plasma flame.

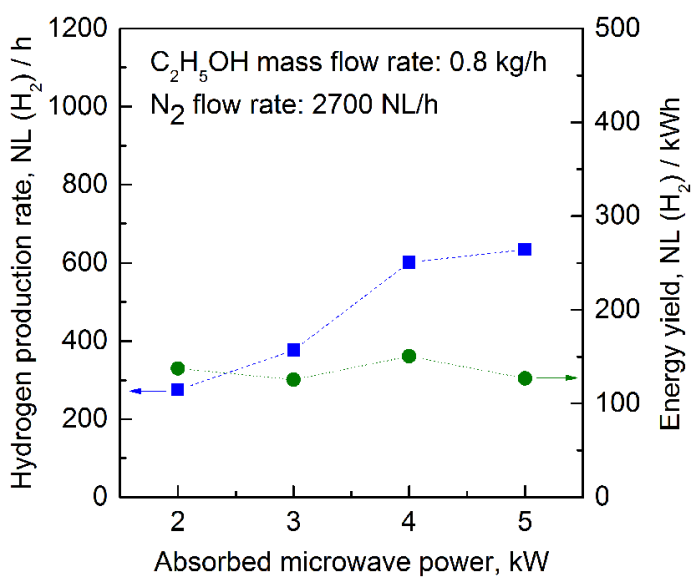

Fig. 6. Hydrogen production rate and energy yield of hydrogen production as a function of absorbed microwave power. $\mathrm{N}_{2}$ swirl flow rate $-2700 \mathrm{NL} / \mathrm{h}, \mathrm{C}_{2} \mathrm{H}_{5} \mathrm{OH}$ mass flow rate $-0.8 \mathrm{~kg} / \mathrm{h}$.

production in $\mathrm{NL}\left(\mathrm{H}_{2}\right) / \mathrm{kWh}$, hydrogen volume concentration in the outlet gas in $\%$, and soot production.

\section{Results and discussion}

The hydrogen production rate, energy yield and hydrogen volume concentration in the outlet gas as a function of absorbed microwave power are shown in Figures 6 and 7 . The measurements were carried out at the $\mathrm{N}_{2}$ flow rate of $2700 \mathrm{NL} / \mathrm{h}, \mathrm{C}_{2} \mathrm{H}_{5} \mathrm{OH}$ mass flow rate of $0.8 \mathrm{~kg} / \mathrm{h}$ and absorbed microwave power varied from $2 \mathrm{~kW}$ to $5 \mathrm{~kW}$. As it is seen from Figures 6 and 7 increasing the absorbed microwave power resulted in an increase in the hydrogen production rate and the hydrogen volume concentration in the outlet gas. When the absorbed microwave power increased from $2 \mathrm{~kW}$ to $5 \mathrm{~kW}$, the hydrogen production rate increased from $275 \mathrm{NL}\left(\mathrm{H}_{2}\right) / \mathrm{h}$ to $634 \mathrm{NL}\left(\mathrm{H}_{2}\right) / \mathrm{h}$, the hydrogen volume concentration in the outlet gas increased from $9 \%$ to $19 \%$, while the energy yield of hydrogen production remained almost constant at $134 \mathrm{NL}\left(\mathrm{H}_{2}\right) / \mathrm{kWh}$.

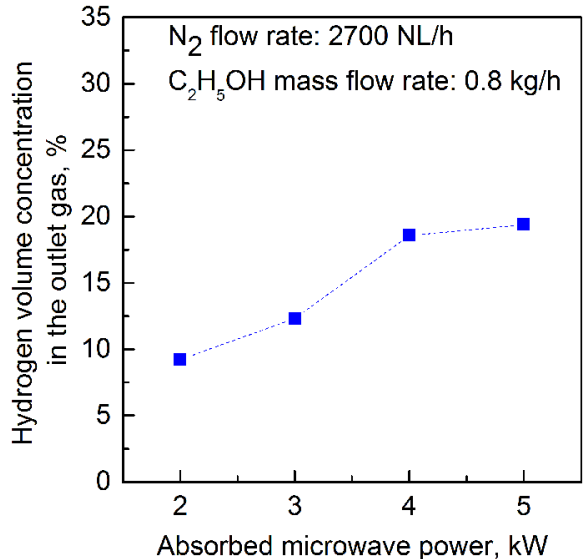

Fig. 7. Hydrogen volume concentration in the outlet gas as a function of absorbed microwave power. $\mathrm{N}_{2}$ swirl flow rate $2700 \mathrm{NL} / \mathrm{h}, \mathrm{C}_{2} \mathrm{H}_{5} \mathrm{OH}$ mass flow rate $-0.8 \mathrm{~kg} / \mathrm{h}$.

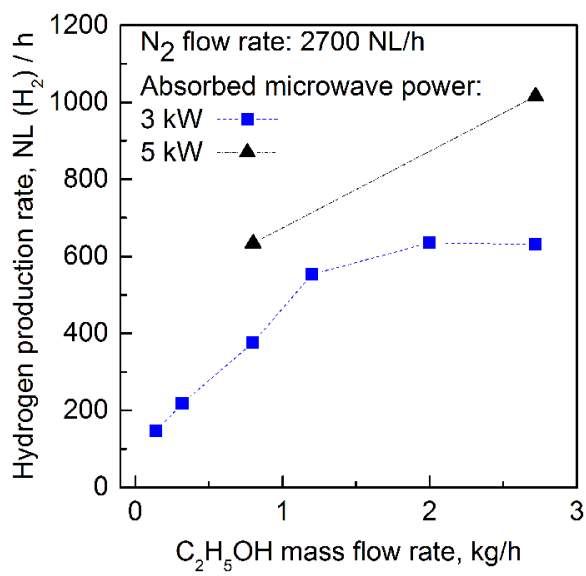

Fig. 8. Hydrogen production rate as a function of $\mathrm{C}_{2} \mathrm{H}_{5} \mathrm{OH}$ mass flow rate. $\mathrm{N}_{2}$ swirl flow rate $-2700 \mathrm{NL} / \mathrm{h}$, absorbed microwave power $3 \mathrm{~kW}$ and $5 \mathrm{~kW}$.

Figures 8-10 show dependence of the hydrogen production rate, energy yield of hydrogen production and hydrogen volume concentration in the outlet gas on $\mathrm{C}_{2} \mathrm{H}_{5} \mathrm{OH}$ mass flow rate (varied from $0.14 \mathrm{~kg} / \mathrm{h}$ to $2.7 \mathrm{~kg} / \mathrm{h}$ ). Two cases are presented. The first one is for $3 \mathrm{~kW}$ and the second for $5 \mathrm{~kW}$ of an absorbed microwave power. As seen, all the three parameters of MPS performance increased when increasing $\mathrm{C}_{2} \mathrm{H}_{5} \mathrm{OH}$ mass flow rate. The hydrogen production rate and hydrogen volume concentration in the outlet gas were higher for higher microwave power $(5 \mathrm{~kW})$, while the energy yield behaved oppositely. At an absorbed microwave power of $5 \mathrm{~kW}$ and $\mathrm{C}_{2} \mathrm{H}_{5} \mathrm{OH}$ mass flow rate of $2.7 \mathrm{~kg} / \mathrm{h}$ the hydrogen production rate was $1016 \mathrm{NL}\left(\mathrm{H}_{2}\right) / \mathrm{h}$, which corresponds to the energy yield of hydrogen production $203 \mathrm{NL}\left(\mathrm{H}_{2}\right) / \mathrm{kWh}$.

For an absorbed microwave power of $3 \mathrm{~kW}$ the saturation effect of the hydrogen production rate, energy yield of hydrogen production and hydrogen volume concentration in the outlet gas with increasing $\mathrm{C}_{2} \mathrm{H}_{5} \mathrm{OH}$ mass flow rate occurs. It seems that at an absorbed microwave power of $3 \mathrm{~kW}$ the $\mathrm{C}_{2} \mathrm{H}_{5} \mathrm{OH}$ reforming capability of the system used 


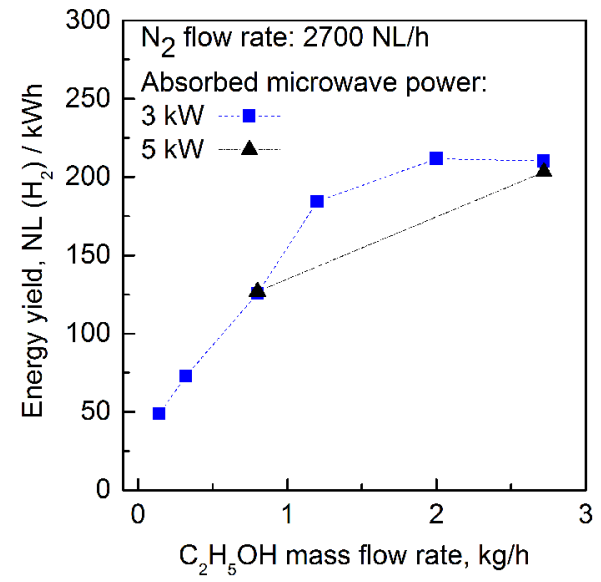

Fig. 9. Energy yield of hydrogen production as a function of $\mathrm{C}_{2} \mathrm{H}_{5} \mathrm{OH}$ mass flow rate. $\mathrm{N}_{2}$ swirl flow rate $-2700 \mathrm{NL} / \mathrm{h}$, absorbed microwave power $3 \mathrm{~kW}$ and $5 \mathrm{~kW}$.

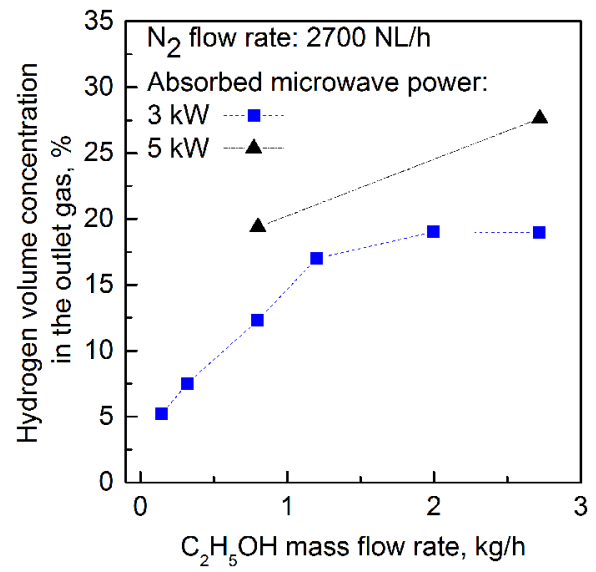

Fig. 10. Hydrogen volume concentration in the outlet gas as a function of $\mathrm{C}_{2} \mathrm{H}_{5} \mathrm{OH}$ mass flow rate. $\mathrm{N}_{2}$ swirl flow rate $2700 \mathrm{NL} / \mathrm{h}$, absorbed microwave power $3 \mathrm{~kW}$ and $5 \mathrm{~kW}$.

is reaching its limits at a $\mathrm{C}_{2} \mathrm{H}_{5} \mathrm{OH}$ mass flow rate of about $2 \mathrm{~kg} / \mathrm{h}$. However, further improvement of the reforming parameters is possible on the expense of higher absorbed microwave power.

Analysis of the gaseous products after the $\mathrm{C}_{2} \mathrm{H}_{5} \mathrm{OH}$ plasma reforming shows that the outlet gas contained: hydrogen, methane $\left(\mathrm{CH}_{4}\right)$, acetylene $\left(\mathrm{C}_{2} \mathrm{H}_{2}\right)$, ethylene $\left(\mathrm{C}_{2} \mathrm{H}_{4}\right)$, ethane $\left(\mathrm{C}_{2} \mathrm{H}_{6}\right)$, oxygen $\left(\mathrm{O}_{2}\right)$, carbon monoxide (CO), carbon dioxide $\left(\mathrm{CO}_{2}\right)$, soot and obviously nitrogen. The concentrations of gaseous compounds resulting from $\mathrm{C}_{2} \mathrm{H}_{5} \mathrm{OH}$ plasma reforming for the nitrogen swirl flow rate of $2700 \mathrm{NL} / \mathrm{h}, \mathrm{C}_{2} \mathrm{H}_{5} \mathrm{OH}$ flow rate of $2.7 \mathrm{~kg} / \mathrm{h}$ and absorbed microwave power of $5 \mathrm{~kW}$ are given in Table 1 .

As expected, soot was produced during the $\mathrm{C}_{2} \mathrm{H}_{5} \mathrm{OH}$ plasma reforming. The soot was filtered out in the gas-soot separator. The amount of the soot deposited on the gassoot separator filter was not measured. Not surprisingly any soot was not present in the plasma generation region and no malfunction of the MPs was monitored.

The record parameters (achieved not necessary in the same conditions) of the hydrogen production by plasma
Table 1. Concentrations of gaseous compounds resulting from $\mathrm{C}_{2} \mathrm{H}_{5} \mathrm{OH}$ plasma reforming. $\mathrm{N}_{2}$ swirl flow rate $2700 \mathrm{NL} / \mathrm{h}, \mathrm{C}_{2} \mathrm{H}_{5} \mathrm{OH}$ mass flow rate $-2.7 \mathrm{~kg} / \mathrm{h}$, absorbed microwave power $5 \mathrm{~kW}$.

\begin{tabular}{ll}
\hline Compound & Concentration, \% \\
\hline $\mathrm{H}_{2}$ & 27.6 \\
$\mathrm{CH}_{4}$ & 4.8 \\
$\mathrm{C}_{2} \mathrm{H}_{2}$ & 4.3 \\
$\mathrm{C}_{2} \mathrm{H}_{4}$ & 3.7 \\
$\mathrm{C}_{2} \mathrm{H}_{6}$ & 0.2 \\
$\mathrm{O}_{2}$ & 1.0 \\
$\mathrm{CO}$ & 10.2 \\
$\mathrm{CO}_{2}$ & 0.2 \\
$\mathrm{~N}_{2}$ & 47 \\
\hline
\end{tabular}

reforming of $\mathrm{C}_{2} \mathrm{H}_{5} \mathrm{OH}$ vapour injected into the microwave nitrogen plasma flame were: the hydrogen production rate $-1016 \mathrm{NL}\left(\mathrm{H}_{2}\right) / \mathrm{h}$ (Fig. 8), the energy yield $-212 \mathrm{NL}\left(\mathrm{H}_{2}\right)$ per $\mathrm{kWh}$ of absorbed microwave energy (Fig. 9) and the hydrogen volume concentration in the outlet gas $-27.6 \%$ (Fig. 10). It is worth noting that all these parameters were attained when $\mathrm{C}_{2} \mathrm{H}_{5} \mathrm{OH}$ mass flow rate was relatively high $\left[2.7 \mathrm{C}_{2} \mathrm{H}_{5} \mathrm{OH} \mathrm{kg} / \mathrm{h}\right]$. These record results are better than those obtained in our investigations presented in [18-20], in which different methods of $\mathrm{C}_{2} \mathrm{H}_{5} \mathrm{OH}$ supply to the microwave plasma (in the form of either a swirl or axial flow) were employed (the comparison only applies to those cases when the working gas was $\mathrm{N}_{2}$ and the $\mathrm{C}_{2} \mathrm{H}_{5} \mathrm{OH}$ vapour was produced in the induction heating vapourizer). When the $\mathrm{C}_{2} \mathrm{H}_{5} \mathrm{OH}$ vapour was produced in the bubble vapourizer [18] the hydrogen production rate $\left(202 \mathrm{NL}\left(\mathrm{H}_{2}\right) / \mathrm{h}\right)$ the energy yield $\left(67 \mathrm{NL}\left(\mathrm{H}_{2}\right) / \mathrm{kWh}\right)$ and the hydrogen volume concentration in the outlet gas $(5 \%)$ where much lower than those attained using the induction heating vapourizer due to a lower $\mathrm{C}_{2} \mathrm{H}_{5} \mathrm{OH}$ mass flow rate (at most $0.4 \mathrm{~kg} / \mathrm{h}$ ) in the former case. However, if we determine a ratio $M$ of the hydrogen production rate to the $\mathrm{C}_{2} \mathrm{H}_{5} \mathrm{OH}$ mass flow rate, which defines how much hydrogen is produced per unit mass of $\mathrm{C}_{2} \mathrm{H}_{5} \mathrm{OH}$ used, the best performing regarding the $M$ ratio belongs to the technique which $\mathrm{C}_{2} \mathrm{H}_{5} \mathrm{OH}$ vapour was supplied into the microwave plasma region in the form of a swirl (with either the bubble or induction vapourizer) $[18,19]$. When supplying the $\mathrm{C}_{2} \mathrm{H}_{5} \mathrm{OH}$ vapour in the form of a swirl flow the $M$ ratio was 2-3 times higher than those obtained for the axial [20] and "into the plasma flame" (present work) supplies of $\mathrm{C}_{2} \mathrm{H}_{5} \mathrm{OH}$ vapour to the system.

The comparison of the three $\mathrm{C}_{2} \mathrm{H}_{5} \mathrm{OH}$ supply systems: as the swirl flow, as the axial flow and "into the plasma flame" one (all three with the induction vapourizer) at the same $\mathrm{C}_{2} \mathrm{H}_{5} \mathrm{OH}$ mass flow rate seems to be more appropriate (the $M$ ratio is the same). The results are given in Figures 11-13. As it can be seen from those figures the difference in the hydrogen production parameters for the three methods are not significant, taking into account the accuracy in such experiments.

It seems that the essential difference in the three supply system performance is the soot production and its influence on the MPS functioning. The swirl system (also that with the bubble vapourizer) is characterised by a 


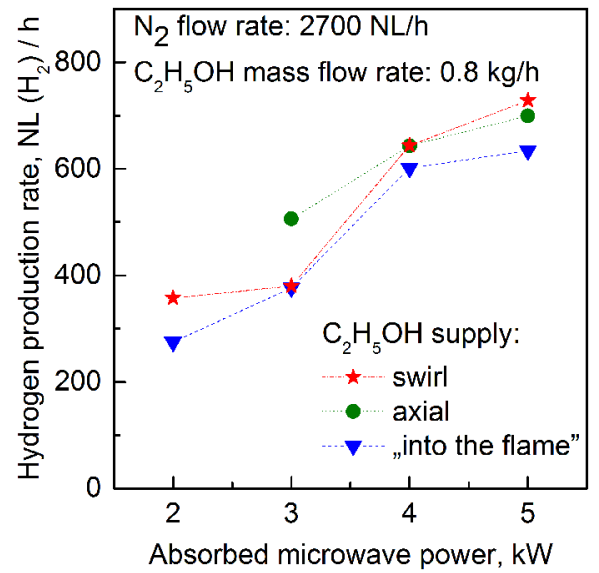

Fig. 11. Comparison of the hydrogen production rate as a function of absorbed microwave power for three $\mathrm{C}_{2} \mathrm{H}_{5} \mathrm{OH}$ supply systems (as the swirl flow [19], as the axial flow [20] and "into the plasma flame" one (all three with the induction vapourizer) at the same $\mathrm{C}_{2} \mathrm{H}_{5} \mathrm{OH}$ mass flow rate), $\mathrm{N}_{2}$ swirl flow rate $-2700 \mathrm{NL} / \mathrm{h}, \mathrm{C}_{2} \mathrm{H}_{5} \mathrm{OH}$ mass flow rate $-0.8 \mathrm{~kg} / \mathrm{h}$.

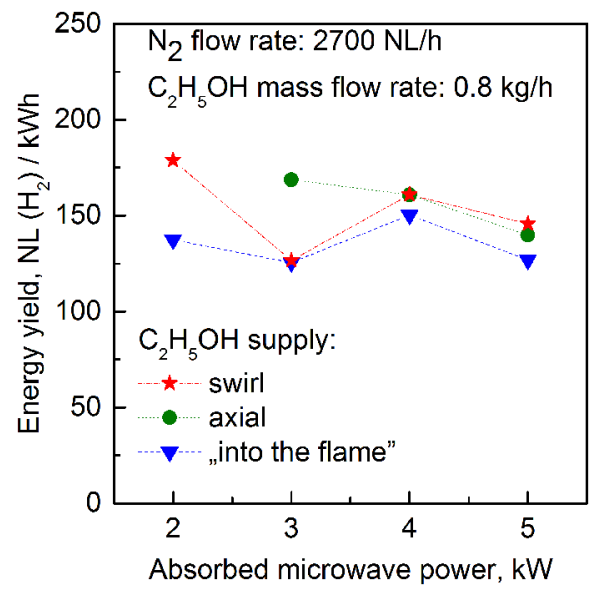

Fig. 12. Comparison of the energy yield of hydrogen production as a function of absorbed microwave power for three $\mathrm{C}_{2} \mathrm{H}_{5} \mathrm{OH}$ supply systems (as the swirl flow [19], as the axial flow [20] and "into the plasma flame" one (all three with the induction vapourizer) at the same $\mathrm{C}_{2} \mathrm{H}_{5} \mathrm{OH}$ mass flow rate), $\mathrm{N}_{2}$ swirl flow rate $-2700 \mathrm{NL} / \mathrm{h}, \mathrm{C}_{2} \mathrm{H}_{5} \mathrm{OH}$ mass flow rate $-0.8 \mathrm{~kg} / \mathrm{h}$.

relatively high soot production in the plasma generation region, which causes the malfunction of the MPS when the $\mathrm{C}_{2} \mathrm{H}_{5} \mathrm{OH}$ mass flow rate increases $0.8 \mathrm{~kg} / \mathrm{h}$. This limits the operation of the MPS with the swirl supply system to the $\mathrm{C}_{2} \mathrm{H}_{5} \mathrm{OH}$ mass flow rates lower than $0.8 \mathrm{~kg} / \mathrm{h}$. The MPS with the axial supply system was tested to operate reliably at the $\mathrm{C}_{2} \mathrm{H}_{5} \mathrm{OH}$ mass flow rate as high as $2.4 \mathrm{~kg} / \mathrm{h}$. The presented MPS, with $\mathrm{C}_{2} \mathrm{H}_{5} \mathrm{OH}$ supplied to the nitrogen plasma flame, may function correctly with very high $\mathrm{C}_{2} \mathrm{H}_{5} \mathrm{OH}$ mass flow rates. However, although the present investigations showed that introducing much $\mathrm{C}_{2} \mathrm{H}_{5} \mathrm{OH}$ vapour $(2.7 \mathrm{~kg} / \mathrm{h})$ into the nitrogen plasma flame resulted in the hydrogen production rate $\left(1016 \mathrm{NL}\left(\mathrm{H}_{2}\right) / \mathrm{h}\right)$ and the energy yield $\left(212 \mathrm{NL}\left(\mathrm{H}_{2}\right) / \mathrm{kWh}\right)$ higher than those of the other $\mathrm{C}_{2} \mathrm{H}_{5} \mathrm{OH}$ supply systems, the $M$ ratio for

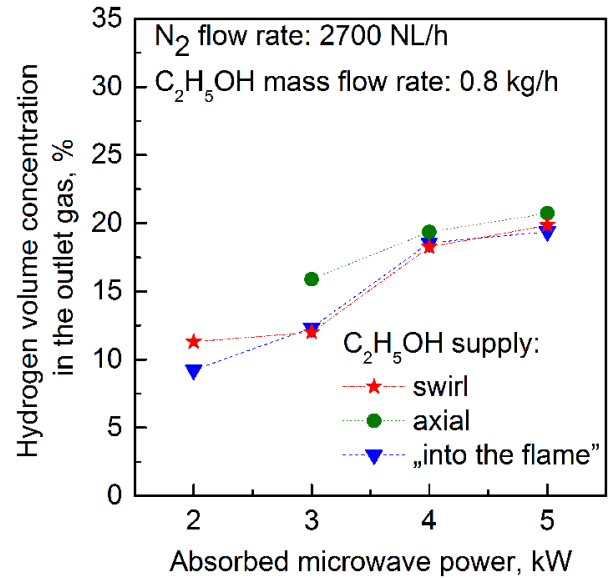

Fig. 13. Comparison of the hydrogen volume concentration in the outlet gas as a function of absorbed microwave power for three $\mathrm{C}_{2} \mathrm{H}_{5} \mathrm{OH}$ supply systems (as the swirl flow [19], as the axial flow [20] and "into the plasma flame" one (all three with the induction vapourizer) at the same $\mathrm{C}_{2} \mathrm{H}_{5} \mathrm{OH}$ mass flow rate), $\mathrm{N}_{2}$ swirl flow rate $-2700 \mathrm{NL} / \mathrm{h}, \mathrm{C}_{2} \mathrm{H}_{5} \mathrm{OH}$ mass flow rate $-0.8 \mathrm{~kg} / \mathrm{h}$.

the "into the plasma flame" is much lower than for the other systems. This means that the $\mathrm{C}_{2} \mathrm{H}_{5} \mathrm{OH}$ introduced into the plasma flame is less efficiently converted into $\mathrm{H}_{2}$ than in the other systems. However, it seems that some improvement in this aspect is possible.

\section{Summary and conclusions}

Hydrogen production by the conversion of $\mathrm{C}_{2} \mathrm{H}_{5} \mathrm{OH}$ using atmospheric pressure microwave plasma produced in the waveguide-supplied metal-cylinder-based MPS was studied experimentally. However in contrast to our earlier investigations, in this case $\mathrm{C}_{2} \mathrm{H}_{5} \mathrm{OH}$ vapour was supplied from the induction vapourizer directly into the plasma flame behind the plasma generation region. The influence of the absorbed microwave power and the $\mathrm{C}_{2} \mathrm{H}_{5} \mathrm{OH}$ mass flow rate on the hydrogen production efficiency parameters: the hydrogen production rate, the energy yield of hydrogen production and the hydrogen volume concentration in the outlet gas was investigated. The investigations showed that increasing the absorbed microwave power resulted in a higher hydrogen production rate and higher hydrogen volume concentration in the outlet gas. With increasing $\mathrm{C}_{2} \mathrm{H}_{5} \mathrm{OH}$ mass flow rate the values of all hydrogen production efficiency parameters increased. The record achieved results of hydrogen production rate, energy yield and hydrogen volume concentration were $1016 \mathrm{NL}\left(\mathrm{H}_{2}\right) / \mathrm{h}, 212 \mathrm{NL}\left(\mathrm{H}_{2}\right) / \mathrm{kWh}$ and $27.6 \%$, respectively. These and other results obtained in the present investigations, when $\mathrm{C}_{2} \mathrm{H}_{5} \mathrm{OH}$ vapour was supplied directly into the plasma flame behind the plasma generation region, were compared with those of our earlier investigations, in which two different $\mathrm{C}_{2} \mathrm{H}_{5} \mathrm{OH}$ vapour supply methods were used $\left(\mathrm{C}_{2} \mathrm{H}_{5} \mathrm{OH}\right.$ vapour was supplied as either the swirl flow or the axial flow). As found the essential difference in the three supply system 
performances was the soot production and its influence on the MPS functioning. The MPS with $\mathrm{C}_{2} \mathrm{H}_{5} \mathrm{OH}$ supplied directly into the plasma flame could operate reliably with very high $\mathrm{C}_{2} \mathrm{H}_{5} \mathrm{OH}$ mass flow rates (up to a few $\mathrm{kg} / \mathrm{h}$ ), which was intuitively expected. The two other MPS (with either the swirl flow or the axial flow $\mathrm{C}_{2} \mathrm{H}_{5} \mathrm{OH}$ supply system) exhibited malfunctioning because of soot production during the $\mathrm{C}_{2} \mathrm{H}_{5} \mathrm{OH}$ plasma reforming.

The main advantage of using the direct supply of $\mathrm{C}_{2} \mathrm{H}_{5} \mathrm{OH}$ into the plasma flame behind the plasma generation region, i.e. a reliable MPS operation due to the absence of $\mathrm{C}_{2} \mathrm{H}_{5} \mathrm{OH}$ vapour in the plasma-generating gas (in nitrogen in our case) can be attractive when other $\mathrm{C}_{2} \mathrm{H}_{5} \mathrm{OH}$ reforming processes (dry, steam, partialoxidation or auto-thermal reforming) or other hydrogen precursors (e.g. kerosene) are to be investigated.

We are grateful to The National Science Centre, Poland (programme no. 2012/05/B/ST8/02789) for financial support of this work.

\section{Author contribution statement}

All the authors contributed equally to the manuscript. Manuscript has been approved by all co-authors.

Open Access This is an open access article distributed under the terms of the Creative Commons Attribution License (http://creativecommons.org/licenses/by/4.0), which permits unrestricted use, distribution, and reproduction in any medium, provided the original work is properly cited.

\section{References}

1. I. Dincer, C. Acar, Int. J. Hydrogen Energy 40, 11094 (2015)

2. P. Nikolaidis, A. Poullikkas, Renew. Sustain. Energy Rev. 67, 597 (2017)
3. C.M. Kalamaras, A.M. Efstathiou, Conf. Pap. Energy 2013, 690627 (2013)

4. J.D. Holladay, J. Hu, D.L. King, Y. Wang, Catal. Today 139, 244 (2009)

5. Hydrogen energy and fuel cells: a vision of our future. Final report of the high level group. European Commission Special Report, EUR 20719 EN, 2003

6. K. Randolph, U.S. DOE Hydrogen Production. Annual Merit Review and Peer Evaluation Meeting, May 16, 2013

7. R. Rincón, A. Marinas, J. Muñoz, C. Melero, M.D. Calzada, Chem. Eng. J. 284, 1117 (2016)

8. J. Mizeraczyk, M. Jasiński, Eur. Phys. J.: Appl. Phys. 75, $24702(2016)$

9. C. Du, H. Li, L. Zhang, J. Wang, D. Huang, M. Xiao, J. Cai, Y. Chen, H. Yan, Y. Xiong, Y. Xiong, Int. J. Hydrogen Energy 37, 8318 (2012)

10. S. Sun, W. Yan, P. Sun, J. Chen, Energy 44, 911 (2012)

11. Y. Sekine, K. Urasaki, S. Asai, M. Matsukata, E. Kikuchia, S. Kadob, Chem. Commun. 1, 78 (2005)

12. V.V. Yukhymenko, V.Ya. Chernyak, S.V. Olszewski, S.M. Sidoruk, V.P. Demchina, D.S. Levko, A.I. Shchedrin, in Problems of atomic science and technology. Plasma physics (Kharkiv Institute of Physics and Technology, Kharkov, Ukraine, 2011), Vol. 17, p. 101

13. D. Czylkowski, B. Hrycak, R. Miotk, M. Jasiński, J. Mizeraczyk, M. Dors, Nukleonika 61, 185 (2016)

14. J. Mizeraczyk, M. Jasiński, H. Nowakowska, M. Dors, Nukleonika 57, 241 (2012)

15. D. Czylkowski, B. Hrycak, M. Jasiński, M. Dors, J. Mizeraczyk, Energy 113, 653 (2016)

16. D.L. Trimm, Catal. Rev. Sci. Eng. 16, 155 (1977)

17. J. Rostrup-Nielsen, D.L. Trimm, J. Catal. 48, 155 (1977)

18. B. Hrycak, D. Czylkowski, R. Miotk, M. Dors, M. Jasiński, J. Mizeraczyk, Int. J. Hydrogen Energy 39, 14184 (2014)

19. B. Hrycak, D. Czylkowski, R. Miotk, M. Dors, M. Jasiński, J. Mizeraczyk, Open Chem. 13, 1 (2015)

20. D. Czylkowski, B. Hrycak, R. Miotk, M. Jasiński, M. Dors, J. Mizeraczyk, Int. J. Hydrogen Energy 40, 14039 (2015) 